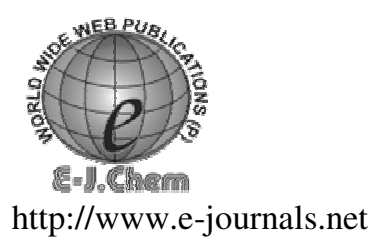

ISSN: 0973-4945; CODEN ECJHAO

E-Journal of Chemistry

Vol. 5, No.2, pp. 377-384, April 2008

\title{
Study on the Quality of Water in Some Streams of Cauvery River
}

\author{
ABIDA BEGUM and HARIKRISHNA \\ Department of Chemistry, P.E.S School of Engineering, Bangalore- 560100 \\ Shirdi Sai Engg. College, Bangalore. Visveshwaraya Technological University, Belgaum, \\ drabid.drabida@gmail.com
}

Received 30 October 2007; Accepted 20 December 2007

\begin{abstract}
The quality of water in four streams of Cauvery River in Mandya District, where many small scale sugar and brewery distilleries are located, was analysed. Sampling was carried out from four streams designated as station 1 (upstream of effluent discharge point), station 2 (effluent discharge point) and station 3 (downstream of effluent discharge) station 4 (fresh water stream) to assess the impact of effluent on the water quality. The river water composition is increasingly dominated by $\mathrm{Na}$ and $\mathrm{Cl}$ in the downstream region of the river, indicating the influence of airborne salts with oceanic affinities. Significant spatial variation was observed in water level, transparency, turbidity, depth, dissolved oxygen, colour, biochemical oxygen demand, nitrate, nitrite and total hydrocarbon among the physiochemical parameters of the study stations. A posteriori test revealed that station $2 \& 3$ were the cause of the significant difference. The dissolved oxygen level in stations $2 \& 3$ was lower than $5.0 \mathrm{mg} / \mathrm{L}$, which is recommended minimum allowable limit for aquatic life. About 7 rotifer species in large amount recorded in this study were encountered in station 1, 7 in station $2 \& 3$ while 12 species in station 4 . The overall density of rotifers in the four stations was significantly different. A posteriori comparison revealed that station $2 \& 3$ are the cause of the significant difference. The Branchionus angularis rotifers, which dominated the community, were found to tolerate the effluent effect in station $2 \& 3$, and showed remarkable recovery in the downstream station 4 . Low faunal diversity and negative impact on the biotic and abiotic environment was experienced in station $2 \& 3$ throughout the duration of sampling because of the brewery effluent discharged directly into these two Streams.
\end{abstract}

Keywords: Sugar and Brewery effluent; Physico-chemical characteristics; Impact Assessment; Water quality; Cauvery River Streams; Rotifier 


\section{Introduction}

As today's technology progresses, the natural environment suffers from the detrimental effects of pollution. The natural process of transportation of metal ions between soil and water consolidates metal contamination, in high concentrations, that affect the areas of natural ecosystems. The growth of human population and rapid industrialization led to increasing use of urban waters as sewers, compromising their other uses ${ }^{1}$. The discharge of industrial effluents has led inevitably, to alterations in the quality and ecology of receiving water bodies. This brings new challenges to both water resource managers and aquatic ecologists. Several attempts have been made to regulate/control the quality of effluents that are discharged from waste generating industries into our water systems. Today, most urban areas of the developing world remain inadequately served by sewage treatment infrastructure. Untreated wastes pose serious threat to associated environment including human health risks ${ }^{2}$. Commonly cited effects of industrial effluents on the receiving waters are high turbidity, reduced transparency, increased suspended solids and oxygen depletion ${ }^{3}$.

Mandya district popularly known as 'Land of Sugar' It is one of the districts with fertile land in south Karnataka. The district is located in the south east of Karnataka State and shares its borders with the districts of Mysore, Hassan, Tumkur and Bangalore. Most of the land is flat, interspersed with hilly region and sparsely vegetated by thorns and bushes. The district is situated at the height of 762 to 914 meters from the sea level.The prominent rivers that have influenced the life of the people of Mandya district are Cauvery, Hemavathi, Lokapavani, Simsha and Veera vaishnavi. Branches of river Cauvery discends from the height of 200 feet at Shivanasamudra of Malavally taluk to form beautiful falls by name * Gaganachukki ' and 'Bharachukki'. Cauvery River and its four tributaries are Hemavathi, Shimsha, Lokapavani, Veeravaishnavi. Soil of the district can be classified into three groups, such as, Red sandy loams, Red clavey loams ,Clavey loams ${ }^{4}$.

Since the sugarcane is the major crop in the district, there are four sugar factories, several khandasari sugar units and many Jaggery producing units. Milk products producing factory, edible oil producing factory, BPL battery factory and several small scale distilleries are there in the district. These Industries generate million tons of molasses and bagasse as by products. The spentwash ( $\mathrm{pH} 4.0-4.4)$ contains organic and inorganic substances capable of producing adverse effects on the physical, chemical and biotic components of the environment and also directly or indirectly on human health. The use of zooplankton and other invertebrates as bio-indicators of water quality has been advocated by several workers $^{4-6}$ because they produce evidence of relatively stable conditions compared with chemical and microbiological data, which only indicate short-term alterations. This study is an interdisciplinary research designed to investigate all possible anthropogenic impacts on the water quality and fauna of the Cauvery River. The effects of sugar and distilleries effluents on the water quality and rotifer community of the Cauvery River are documented in this report.

\section{Data collection and analysis}

This study was carried out in 4 streams of Cauvery River. The Cauvery River is one of the major rivers of India, which is considered sacred. The river originates at Talakaveri in the western ghats in the state of Karnataka, flows generally south and east through Karnataka and Tamil Nadu and across the southern Deccan plateau through the southeastern lowlands, emptying into the Bay of Bengal through two principal mouths. 
The Kaveri River basin is estimated to be 27,700 square miles with many tributaries including the Shimsha the Hemavathi River, the Arakavathy River, Honnuhole River, LakshmanaTirthaRiver, Kabini River, Bhavani River, the Lokapavani River, the Noyyal River and the Amaravathi River. Rising in southwestern Karnataka state, it flows southeast some $475 \mathrm{mi}(765 \mathrm{~km})$ to enter the Bay of Bengal. East of the city of Mysore it forms the island of Sivanasmudra, on either side of which are the scenic Sivnasamudram Falls that descend about $320 \mathrm{ft}(100 \mathrm{~m})$. The primary uses of Kaveri are providing water for irrigation, water for household consumption and the generation of electricity. The cauvery, like many major rivers in general, in India faces many problems, including dry summers, wetland filling, large dams, and pollution ${ }^{7}$.

\section{Experimental}

Four sampling stations (located at the point where Sugar and distilleries effluent is discharged, it's upstream and downstream) were selected for study. The description of each station is given below:

Station 1 is located about $2.03 \mathrm{~km}$ upstream of the sugar and distilleries effluent discharge point (Hanakere). Station 2 is the distillery effluent discharge point where the major human activities are bathing, laundering and fishing (Muttegere). Stations 3 is about $1.3 \mathrm{~km}$ downstream of a sugar industry, which empties its wastes directly into one stream of the river (Taggahalli). Station 4 is fresh water stream away from pollutants and also not much human activities (Hatna). Methods for sampling i.e., collected samples were preserved in pre-cleaned plastic containers prior to analysis from the above said selected sites, placed in dark boxes and processed with 6 hours of collection; sorting and identification of rotifers were done according to literature study ${ }^{5}$. Water temperature, water level, turbidity, flow velocity and transparency were measured as per the International standard methods. Dissolved oxygen and biological oxygen demand were determined by the Winkler's method. Hydrogen-ion concentration $(\mathrm{pH})$ and conductivity were measured in-situ with the Elico digital $\mathrm{pH}$ and Conductivity meters respectively. Total dissolved solids (TDS) were determined gravimetrically. Phosphate and nitrate were determined colorimetrically while flame photometry was used for the determination of sodium and potassium. Magnesium was measured using Atomic Absorption Spectrophotometer while calcium was analyzed with a Technicon Auto analyzer. Iron was determined spectrophotometrically by the 1:10 phenanthroline method while chromium, copper, lead, zinc, Nickel, Cadmium and Vanadium were determined using the Atomic Absorption Spectrophotometer after appropriate treatment and digestion. Total hydrocarbon in the water sample was extracted with $\mathrm{CCI}_{4}$ at $\mathrm{pH} 5.5$. The $\mathrm{C}-\mathrm{H}$ stretch band obtained was at $2850 \mathrm{~cm}^{-1}$ was calculated and converted to concentration using calibration curve.

The Bio-toxicity study on the effect of water by spent wash on 20 Rotifera community was investigated between September and November 2006. Rotifera were acclimatized to laboratory conditions for about 19 days before experimentation, then utilized in different salmples of water. Population of each Rotifer community ${ }^{8-10}$ was established (Table 2).

\section{Results and Discussion}

The results of the water quality measurement are summarized in (Table 1). Wide variations were observed in measured parameters at all stations (Figure 1). Water depth, transparency, dissolved oxygen, biochemical oxygen demand, colour, nitrate, nitrite and total hydrocarbon 
showed significant spatial variations. Water depth was significantly different in the four stations. Water transparency and dissolved oxygen were significantly lower in station $2 \& 3$ than in stations $1 \& 4$. Colour, turbidity, conductivity, nitrate and nitrite were significantly higher in concentration in station $2 \& 3$ than in stations $1 \& 4$. Total hydrocarbon (THC), and total dissolved solids (TDS), were significantly lower in station 1and 4 than in stations 2 $\& 3$. The parameters were compared with the International Standards ${ }^{11-16}$. Dissolved oxygen level in stations $2 \& 3$ was lower than the minimum allowable limit $(5 \mathrm{mg} / \mathrm{L})$ for aquatic life. Ammonium concentration in all stations except station 4 exceeded the $0.3 \mathrm{mg} / \mathrm{L}$ limit. All other physiochemical parameters including heavy metals were within the recommended limits in all stations.

Table 1. Water quality parameters of water samples collected from 4 Stations of Cauvery River

\begin{tabular}{|c|c|c|c|c|c|}
\hline Parameters $\backslash$ Sample & $\begin{array}{c}\text { WHO } \\
\text { Standards } \\
\end{array}$ & $\begin{array}{c}\text { Station } \\
1 \\
\end{array}$ & $\begin{array}{c}\text { Station } \\
2 \\
\end{array}$ & $\begin{array}{c}\text { Station } \\
3 \\
\end{array}$ & $\begin{array}{c}\text { Station } \\
4 \\
\end{array}$ \\
\hline Water Temp. ${ }^{\circ} \mathrm{C}$ & - & 26 & 24 & 25 & 28 \\
\hline Water level, $\mathrm{cm}$ & - & 88 & 154 & 130 & 102 \\
\hline Flow velocity, $\mathrm{m} \backslash \mathrm{s}$ & - & 0.6 & 0.5 & 0.8 & 0.7 \\
\hline Transparancy, cm & - & 60 & 22 & 32 & 57 \\
\hline Turbidity (NTU) & - & 201 & 1780 & 520 & 270 \\
\hline Colour (Pt. Co.) & 201 & 185 & 246 & 211 & 167 \\
\hline $\mathrm{TDS}, \mathrm{mg} \backslash \mathrm{L}$ & $500-1500$ & 51 & 1480 & 1620 & 153 \\
\hline DO ppm & $5.0-6.0$ & 5.5 & 1.34 & 3.6 & 5.4 \\
\hline $\mathrm{BOD}, \mathrm{mg} \backslash \mathrm{L}$ & $28-30$ & 1.2 & 1.2 & 1.8 & 1.5 \\
\hline $\mathrm{COD}, \mathrm{mg} \backslash \mathrm{L}$ & - & 54 & 25.2 & 17.5 & 23 \\
\hline Conductivity, $\mathrm{mV}$ & - & 3.0 & 8.8 & 55.9 & 3.5 \\
\hline $\mathrm{PH}$ & $7-8.5$ & 6.2 & 5.9 & 5.3 & 6.2 \\
\hline $\mathrm{P}, \mathrm{ppm}$ & 5 & 2.5 & 5.1 & 8.5 & 6.1 \\
\hline $\mathrm{NH}_{3}, \mathrm{ppm}$ & 0.2 & 30 & 15.2 & 6.4 & 5.3 \\
\hline $\mathrm{NO}_{3}, \mathrm{ppm}$ & 20 & 0.0 & 0.0 & 0.05 & 0.01 \\
\hline $\mathrm{NO}_{2}, \mathrm{ppm}$ & - & 0.0 & 0.01 & 0.01 & 0.0 \\
\hline $\mathrm{SO}_{4}, \mathrm{ppm}$ & $42-45$ & 0.4 & 0.08 & 0.09 & 0.0 \\
\hline $\mathrm{Cl}, \mathrm{ppm}$ & $200-600$ & 254 & 229 & 213 & 176 \\
\hline $\mathrm{Na}, \mathrm{ppm}$ & 200 & 6.8 & 40 & 29 & 22 \\
\hline $\mathrm{K}$, ppm & $75-200$ & 6.2 & 16.2 & 12.1 & 12 \\
\hline $\mathrm{Ca}, \mathrm{ppm}$ & $150-200$ & 21 & 19 & 14.4 & 12 \\
\hline $\mathrm{Mg}, \mathrm{ppm}$ & $50-150$ & 23 & 21 & 11.6 & 12.7 \\
\hline $\mathrm{Fe}, \mathrm{ppm}$ & 20 & 5.2 & 2.2 & 0.56 & 0.62 \\
\hline $\mathrm{Mn}, \mathrm{ppm}$ & 0.5 & 0.7 & 0.53 & 0.41 & 0.32 \\
\hline $\mathrm{Zn}, \mathrm{ppm}$ & $<1$ & 0.01 & 0.04 & 0.06 & 0.04 \\
\hline $\mathrm{Cu}, \mathrm{ppm}$ & $<1$ & 0.02 & 1.32 & 1.41 & 0.68 \\
\hline $\mathrm{Cr}, \mathrm{ppm}$ & - & 0.1 & 0.1 & 0.1 & 0.12 \\
\hline $\mathrm{Cd}, \mathrm{ppm}$ & $<1$ & 0.28 & 0.56 & 0.17 & 0.0 \\
\hline $\mathrm{Ni}, \quad \mathrm{ppm}$ & $<1$ & 0.02 & 0.28 & 0.30 & 0.0 \\
\hline $\mathrm{V}, \quad \mathrm{ppm}$ & - & 0.02 & 0.3 & 0.1 & 0.1 \\
\hline $\mathrm{Pb}, \mathrm{ppm}$ & $<1$ & 0.28 & 0.33 & 0.09 & 0.1 \\
\hline $\mathrm{Hg}, \mathrm{ppm}$ & 0.05 & 0.0 & 0.0 & 0.0 & 0.0 \\
\hline $\mathrm{THC}$ & 10 & 0.5 & 0.6 & 0.8 & 0.1 \\
\hline Total Hardness, ppm & $200-600$ & 118 & 117 & 106 & 75 \\
\hline
\end{tabular}


Table 2. Faunal comparision of Rotifera species in 4 stations of Cauvery River

\begin{tabular}{clcccc}
\hline S. & \multicolumn{1}{c}{ Rotifera Species } & Station & Station & Station & Station \\
No. & & 1 & 2 & 3 & 4 \\
\hline 1 & Brachionus angularis, & 2 & 128 & 120 & 4 \\
2 & Trichocerca cylindrica, & - & 98 & 112 & 3 \\
3 & Polyurthra euryptera & 02 & 77 & 24 & - \\
4 & Pompholyx sulcata & 03 & 68 & 56 & - \\
5 & Rotaria rotatoria P. & 03 & 91 & 24 & - \\
6 & Filinia longiseta & 01 & 46 & 55 & - \\
7 & Ascomorpha ovalis & 01 & 111 & 97 & 03 \\
8 & Asplanchna herricki & 02 & 23 & 12 & 04 \\
9 & Synchaeta grandis & 78 & - & - & 81 \\
10 & Ploesoma hudsoni & 99 & - & - & 66 \\
11 & Monostyla Bulla & 57 & - & - & 70 \\
12 & Anuraeopsis fissa & 57 & - & - & 89 \\
13 & M. hamata & 55 & - & - & 67 \\
14 & Brachionus & 40 & - & - & 78 \\
15 & Keratella spec & 60 & - & - & 67 \\
16 & Proales sp. & 95 & 12 & 15 & 55 \\
17 & Testudinella patina Hermann & 500 & 40 & 32 & 810 \\
18 & L. lunaris Ehrenberg & 45 & 04 & 05 & 50 \\
19 & Beauchampiella & 12 & 10 & 09 & 23 \\
& eudactylotaGoose & & & & \\
20 & Dipleuchlanis propatula & 12 & - & - & 23 \\
& Goose & & & & \\
\hline
\end{tabular}

I Rotifera 1-8 are indicators of heavy pollution (Eutrophy), which is more prominent in Station 2 and 3. II Rotifera 9-15,20 are indicators of fresh and clean waters (Oligotrophy) observed in Stations 1 and 4. III Rotirera 16-19 are inhabitants of moderately clean (Mesotrophy) waters observed in all Stations.

Rotifera are the smallest multicelular organisms in the world and they are Bioindicators of water quality. Branchionus angularis, Trichourca cylindrica, Polyeurthra euryptera, Pompholyx sulcatal Rotaria rotatoria, Filinia longiseta have been designated as indicators of heavy pollution (Eutrophy). Ascomorpha ovalis, Asplanchna herricki, Synchaeta grandis, Ploesoma hudsoni, Anuraeopsis fissa, Monostyla bulla and M. hamata are indicators of fresh and clean waters (Oligotrophy) while a variety of rotifers including Brachionus, Keratella spec, are inhabitants of moderately clean (Mesotrophy) waters ${ }^{17-19}$. All the fifteen species were recorded in station 1 . In station $2 \& 3$, the number of species recorded was six and in station 4, the number of species recorded was ten. All indices of diversity used in community analysis, point to high fauna diversity in station 1 and 4 and low diversity ${ }^{20,21}$ in station $2 \& 3$.

The impact of brewery effluent on the Rotifer community cannot be considered exclusively without recourse to the water quality parameters since these singly or synergistically influence cumulative changes in the biotic community. The discharge of effluents directly into station $2 \& 3$ was significantly reduced the water transparency and dissolved oxygen level. Exogenous substances of organic origin are known to increase water colour, turbidity, and suspended and dissolved solids and thus reduce transparency. The biodegradation of organic materials exerts oxygen tension in the water and increases the biochemical oxygen demand. The increased levels of conductivity, nitrate, and cations are 
products of decomposition and mineralization of organic materials, which were present very much in station $2 \& 3$. While most of these impacted parameters easily recovered to their original state downstream, the total dissolved solids and total hydrocarbon still remained high in the downstream station. This can be explained by the low biodegradability of hydrocarbons and dissolved inorganics.
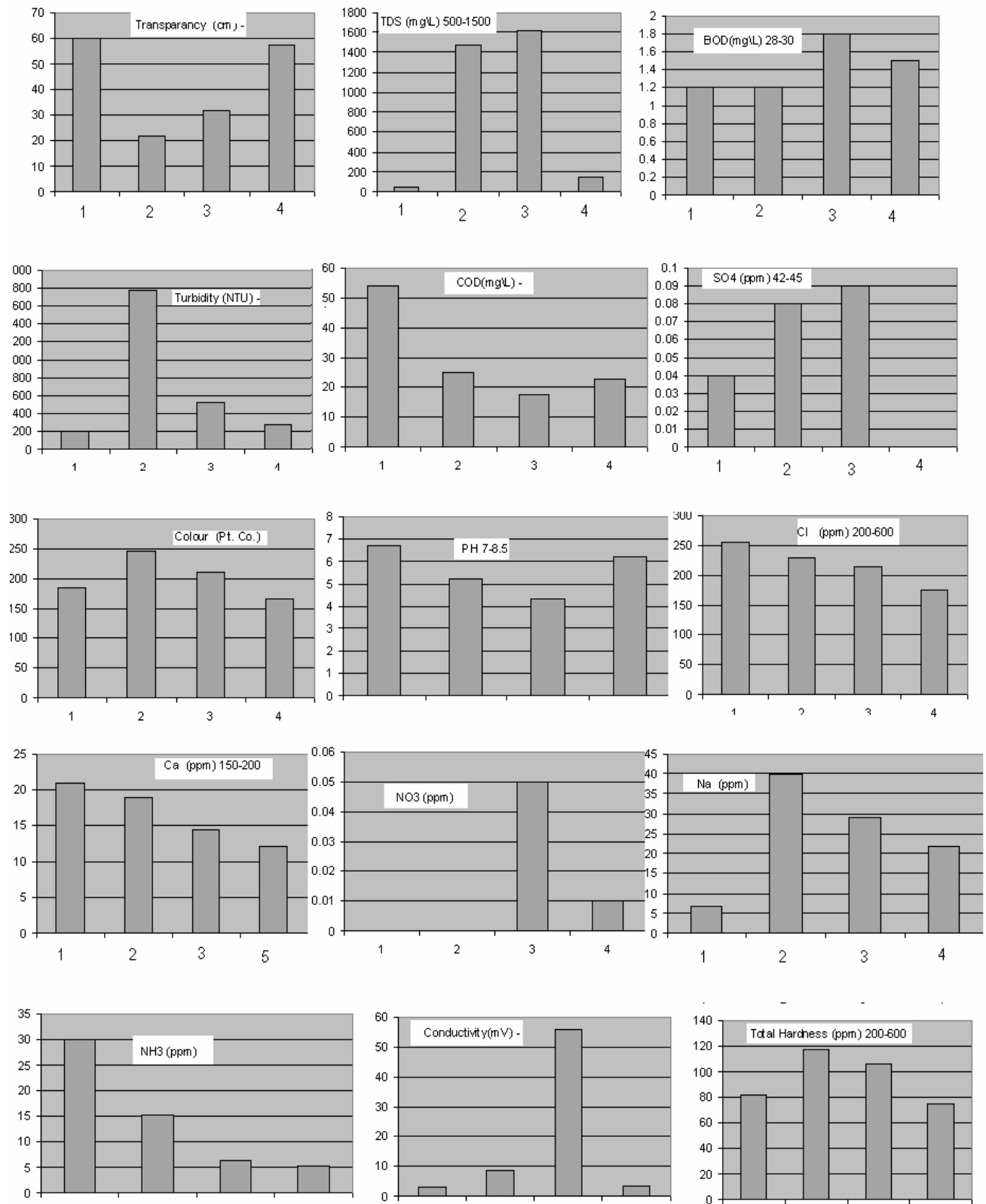

Figure 1. Showing select physico-chemical parameters of various samples of water in 4 stations 


\section{Conclusions}

The response of Rotifera to effluent pollution varied greatly, sensitive species normally disappear as the water becomes polluted while tolerant ones survive the pollution stress and readily recovers downstream of the point of discharge. Their disappearance in the effluent station of this study might have link with factors other than organic pollution. The pollution in station recorded was in $2>3>1>4$ increasing order of magnitude.

The changes observed in the physical properties of receiving water, notably increased TDS, turbidity, $\mathrm{NaCl}$, reduced transparency and dissolved oxygen in Stations $2 \& 3$ indicate inefficient effluent treatment in the distilleries. Common effluent treatment is subject to certain limitations, which means ensuring that industrial effluents have to be pre-treated to prevent interference in the clarifying processes. As these streams fulfill $80 \%$ of domestic water supply demand of the local community, all specified quality criteria must be met especially before the discharge. It is recommended that apart from continuous collection of effluents for monitoring purposes, automated measuring and monitoring equipment be installed to check discharge parameters against stipulated standards for drinking water, aquatic life and other uses.

\section{References}

1. Atkins P W, Physical chemistry. $4^{\text {th }}$ Ed. ELBS with Oxford University press. London, 1991, 652.

2. Chand S \& Dara S S, A Textbook of Environmental Chemistry and Pollution. Control. S Chand \& Co. Ltd, New Delhi, India 1997.

3. Palasnisamy N.S, Geetha A, Sujatha M, Sivakumar P and KarunaKaran K, E-J Chem 2007, 4, 434-439.

4. Eddy N O and Udoh C L, Introduction to Environmental Chemistry, Patom press, Nigeria, 2006, 152.

5. Susheel Kumar Sindhu, Amit Sharma and Saika Ikram, E-J Chem 2007, 4, 390-396.

6. FEPA, Standard range of heavy metals in sediment. Guidelines and standard for environmental pollution control in Nigeria , 1991, 6, 71

7. Manivasakam N, Physical Chemical examination of water, sewage and industrial effluents $3^{\text {rd }}$ Ed, Pragathi Prakashan, Meeret, India, 1996.

8. .Hart CW (Jr) and Fuller SLH Ed. Pollution ecology of freshwater invertebrates. Academic Press, New York. 1974.

9. Coetzee D J, J. Limnol. Soc. Sth. Afr. 1981, 7, 5-12.

10. Rivers of India and water in the Indian Constitution. - Government of India. Retrieved on 2006,11-23.

11. WHO, Guidelines for water quality. Health and other supporting information WHO, Geneva, 1984, 2100.

12. A O A C, Official methods of analysis. Association of Official analytical chemists. $12^{\text {th }}$ Ed. William H, 1975.

13. Kumar V, Wati L, Nigam P, Banat I M, Yadav B S, Singh D and Merchant R, Biochem., 1998, 33,75.

14. WHO/UNEP, Water quality monitoring: A practical guide to the design and Implementation of fresh water quality studies and monitoring programmes. UN press.Rome. 1996, 96. 
15. Standard Methods for the examination of wastewater and waste water, APHA $16^{\text {th }}$ Ed., Washington DC 1985.

16. Ogbeibu A E, Nigerian Journal of Science and Environment, 1998, 1, 117-134.

17. Ogbeibu AE and Oribhabor B J, Journal of Aquatic Sciences, 2001, 16, 132-138.

18. Eddy N O, Physiochemical parameter of water and heavy metal content of water, fish and sediment from the Qua Iboe river estuary. M. Sc. thesis. University of Uyo, 2005, 142.

19. Persoone CG \& De Pauw N (1979). Systems of Biological Indicators for Water Quality Assessment. In: Rovera O, Ed. Biological Aspects of Freshwater Pollution. Pergamon Press. Oxford, $39-75$.

20. Hynes HBN, The Biology of Polluted Water, University of Toronto Press, 1960, 202.

21. Rao $\mathrm{T} \mathrm{S}$ and Viraraghavan $\mathrm{T}$, Treatment of distilleries wastewater (spentwash)Indian Experience, $40^{\text {th }}$ PIWC, 1985, 53-58. 


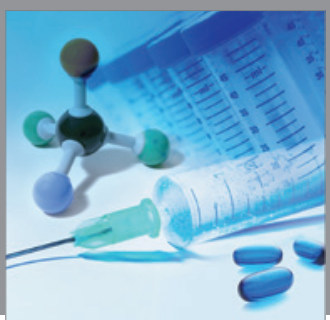

International Journal of

Medicinal Chemistry

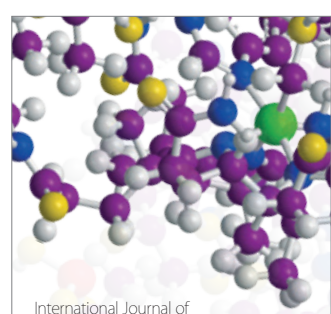

Carbohydrate Chemistry

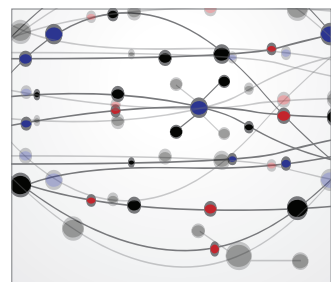

The Scientific World Journal
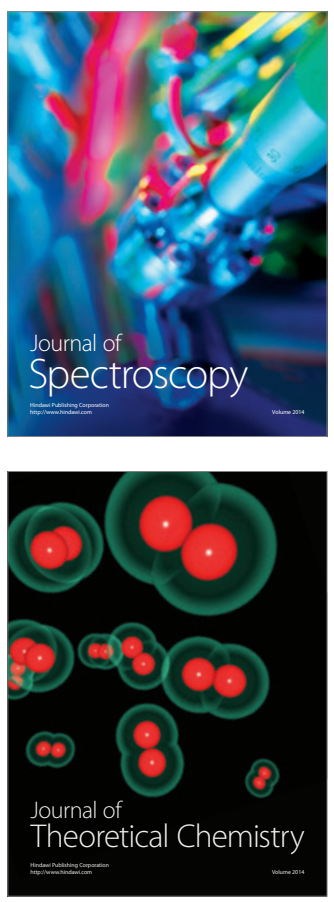
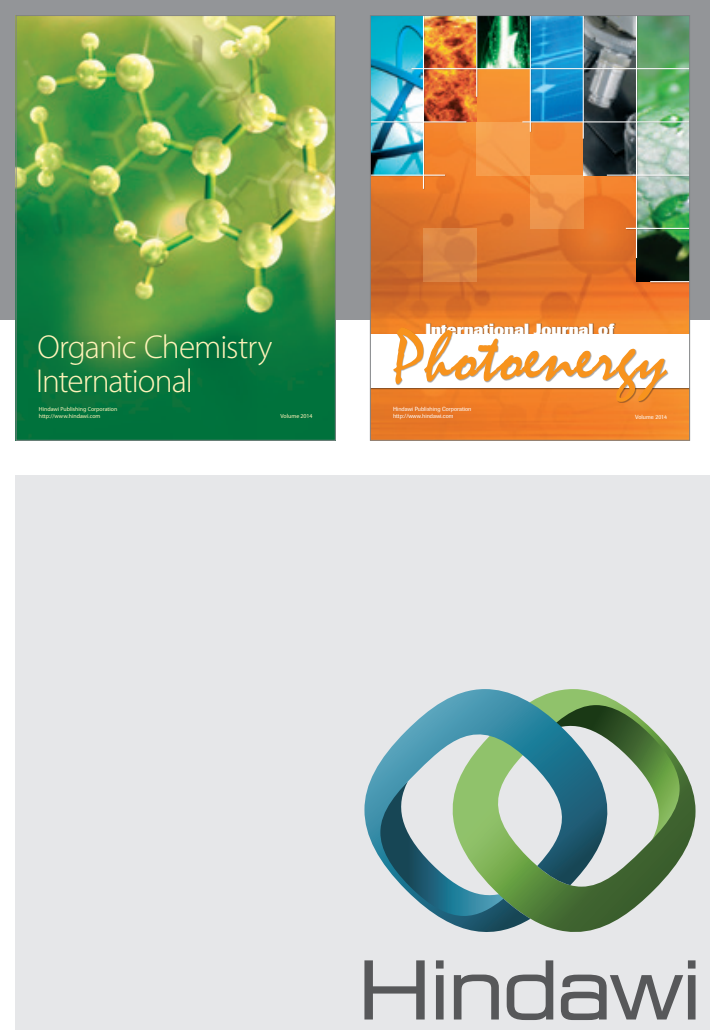

Submit your manuscripts at

http://www.hindawi.com
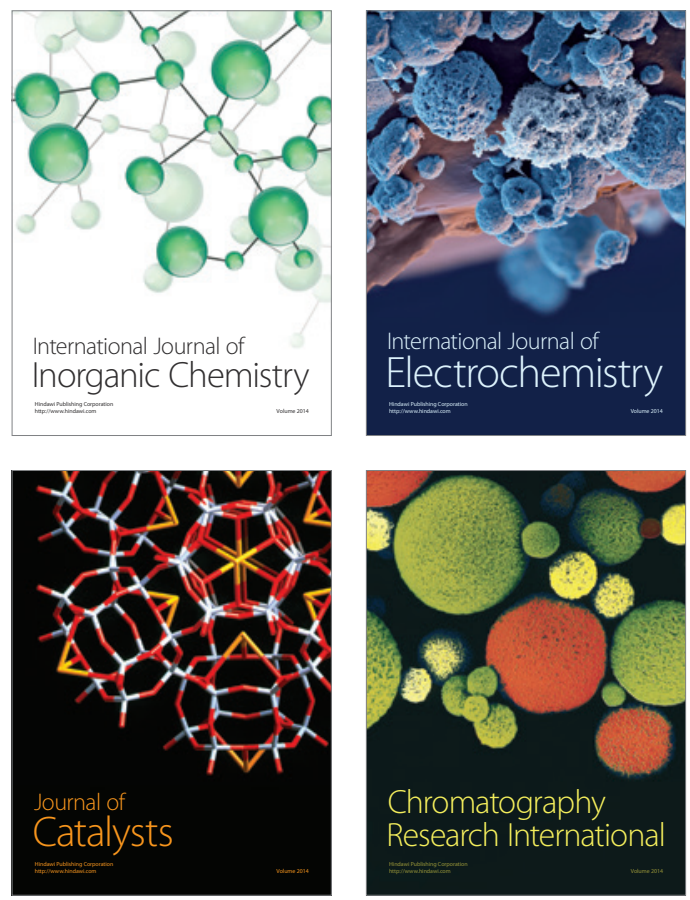
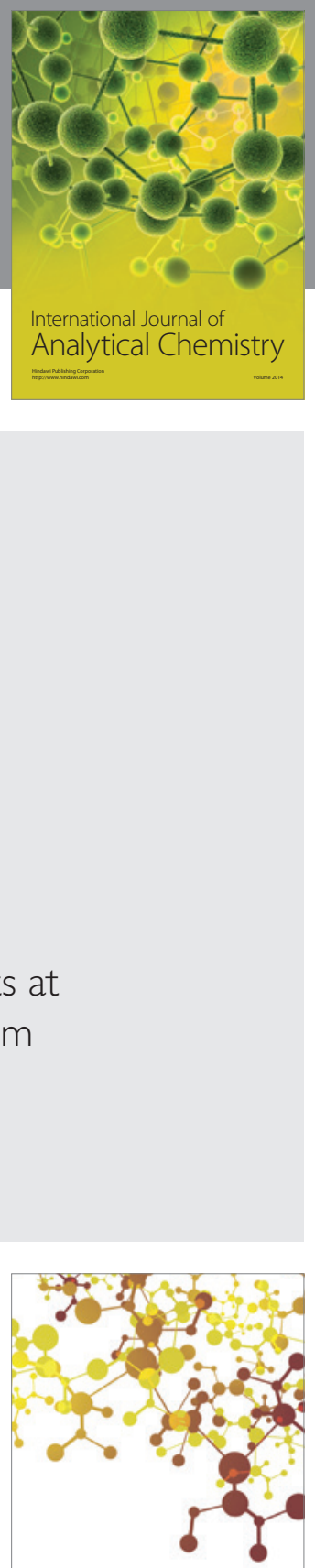

Journal of

Applied Chemistry
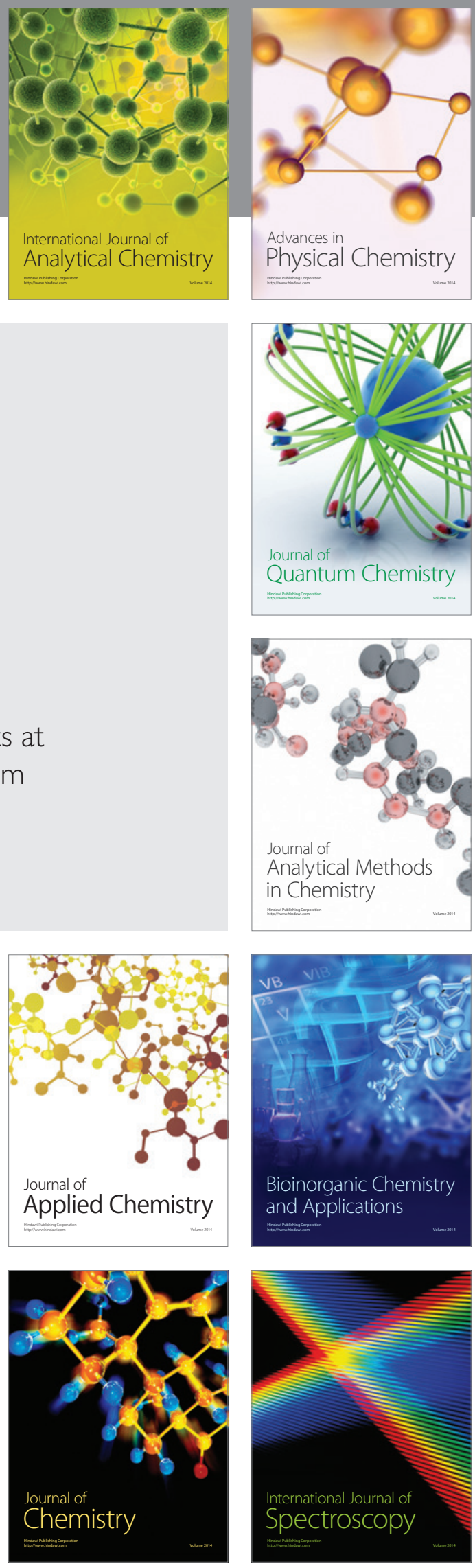